\title{
People who want to live in a more liberal world need to push for it strongly. Interview with Professor Francis Fukuyama, Stanford University
}

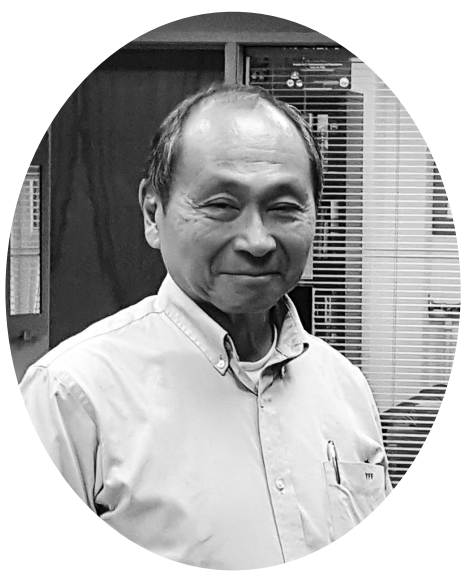

Francis FUKUYAMA is the Olivier Nomellini Senior Fellow at the Freeman Spogli Institute for International Studies (FSI) and the Mosbacher Director of FSI's Center on Democracy, Development, and the Rule of Law (CDDRL). He is also a professor by courtesy in the Department of Political Science. He was previously at the Paul H. Nitze School of Advanced International Studies (SAIS) of Johns Hopkins University, where he was the Bernard L. Schwartz Professor of International Political Economy and director of SAIS’ International Development program.

Let me start with the presidential elections in the USA. Why are the results so controversial and unexpected for many citizens, but for many other countries too? Could the USA be considered as a divided society, after these elections, because of the new era of „populist nationalism”?

Well, first of all, the United States are quite polarized for some time now, [and] for much of the last twenty years it's been growing. This election has increased that polarization in a certain way, and this is quite disturbing, but it is not new. What is new, I think, is the recognition that the working class in the United States is unhappy, and it feels that the leaders of the United States have ignored them, and I think that's largely true. I think the political parties literally haven't found an effective candidate, and Donald Trump saw an opportunity to exploit this situation and especially the popular anger. So, here we are. I think that's a large part of the story of this election. The other thing was that Hillary Clinton was really not a good candidate because she symbolized a lot of the things that people don't like about the leadership. She was very good in putting together a coalition of the interest groups and getting rich in the process, but she did not have a real vision for the country beyond satisfying the identity groups of the democratic coalition. So, I think there are probably a lot of other candidates that could have done much better against Trump. 
The Trump presidency will signal the end of an era in which America symbolized democracy to people living under corrupt authoritarian governments around the world. Could Trump and his authoritarian style be considered an enemy of American democracy?

The first thing to say is that we just don't know what kind of president he'll be. Everyone's been speculating that there really are two Donald Trumps, a good Donald Trump, the businessman, a pragmatist and not a crazy person, who also rationally wants to do well as President. And then there's the crazy Donald Trump, who tweets in the middle of the night and says all these extreme and irrational things. It's very hard to tell. Some of his appointments, for example General Mattis as defense secretary, are good, but the guy that he has just appointed to the EPA doesn't believe in climate change. So, it's really a mixed bag at the moment, and I refuse to speculate about this right now, because in six months we'll know which way Donald Trump emerges.

Actually, you anticipated my next question, because I wanted to ask you which part of Donald Trump will dominate the new President, the nationalist or the negotiator? And the next question is about the nomination, what do you think about the selection process and the persons who are already or could be nominated for the key positions in the government?

It is encouraging that he hasn't filled the secretary of state position yet and apparently Mitt Romney is still a candidate for that position. That surprises me because I would have thought he'll pick somebody more extreme, like Giuliani or Newt Gingrich, and I think it's good that neither of them seem to be a leading candidate. However, we need to wait and see...

What do you think about the future relations between the United States and Russia? The election of Trump was so much celebrated in Russia; they have so many expectations ...

It's very disturbing. I think there are more benefits on the surface than we know, because Donald Trump hasn't said anything critical of Russia during the whole campaign. And, in fact, he had been briefed by the US Intelligence Community about Russian interference in the election. In the third debate, after he was asked about that briefing, he still insisted we did not really know whether they did anything or not, which is very strange, and, I think, very sinister. It makes you think that Russians have some kind of hidden sources of leverage over here, maybe money or something like that... 
Why did Putin become so aggressive? How would you comment on his declaration: "If I want, in a few hours the Russian Army would be in Warsaw, the Baltic states, and Bucharest"? Recently, Lithuanian President Dalia Grybauskaite said: „No leader could stop Putin". She said: "We have to stop Putin in Ukraine". What do you think about the future development of the situation in Ukraine and the role of the US? Trump was not so critical about Putin and the Russian invasion.

I'm very worried about that. I think that normally the United States would be building a defense based on NATO and investing more military capabilities to prevent Russia from taking over all of its neighbours. But with Trump there [in the White House], I'm really worried that he's going to undermine the American guarantee to the Baltics and to Poland and that he will cut a deal... He may at least consider dropping the sanctions. And beyond that, he may give a kind of green light to the Russians doing something much more aggressive, because he's really not giving Ukraine much support. I've never seen a candidate in my lifetime that didn't make any kind of lip service to democracy, human rights, all of these ideals that the United States claims to stand up for. $\mathrm{He}$, basically, seems to like all of these authoritarian leaders, he can deal with them. I think that this is really bad and I think that Ukraine is the country that is the most vulnerable right now.

You are right, this part of Eastern Europe is the most vulnerable. But, also, the situation in other post-totalitarian countries is not so good, especially given the results of the elections in Bulgaria and Moldova, where the new Presidents are pro-Russian. What do you think about the United States' relations with such countries in Eastern Europe?

Trump seems not to have a problem in dealing with anybody. In fact, proRussian and autocratic regimes don't seem to matter to him and I think that is why the actual decision on who will be the secretary of state and defence is postponed. This is because there are a lot of people in the Republican Party who really don't trust Russia and want to have a much tougher line. If these people are running the major agencies, Trump may have some resistance to an open relationship with Putin. I worry a lot about this, but we just have to see how it works out.

What do you think about the future relationship between the President and the Congress? Even if Republicans have a 
majority, how do you see the future cooperation between these two institutions?

It depends on the issues. I think one of the really big fights is over infrastructure, because Trump wants a big infrastructure program, and a big obstacle to that are, actually, the Republicans, the ones who spend money on anything. Where can the United States borrow money and pay for bridges and roads and airports and that kind of things? I'm actually hoping this will happen, because I think this is an area where the working class might gain a lot. Republicans, and the corporate Republicans, especially, will resist this.

\section{And this is realistic - to build a wall in the southern part of the United States?}

Well, it's not going to solve the problem - I mean, a lot of illegal immigrants in the United States don't come across that border, they have visas that then expire and they just stay in the United States. And we have really no way of tracking them. You could enforce the laws if you have employer's sanctions, or punish companies for hiring people without documents, but we don't do that. Trump has not really talked about that, about this part of the problem. I think a wall is just symbolic and linked to the fact that he doesn't like immigrants.

Are these changes the real collapse of the system and the end of liberal democracies? Is this the end of history or a new beginning of history?

No. I think it's really alarming, I think that there are many policies that, so far, Trump has advocated, that I and other progressive people don't like. But, to say that this is the end of democracy is not correct at all. He hasn't shown any willingness to violate any fundamental democratic principles at this point. It's possible, he could. That's simply not happening yet.

\section{So, can we consider that it is a new beginning?}

I think it is more problematic that he has doubted about some important democratic norms. For example, there is his claim that he actually won the popular vote, and that the official election poll is not correct because of all those illegal voters. However, there is no evidence for this. And yet, he keeps asserting that, which undermines the confidence in our election system. A lot of his supporters believe this, and I think that's really bad. He also demonized what he calls the mainstream media channels. It's not the mainstream, it's simply mass media. And he has basically convinced a lot of his supporters that nothing that is said by The New York Times or the CNN is true. I think that is also dangerous. 
How will the new age of populist nationalism change the future international relations?

At one extreme, it could be quite catastrophic. I mean, if he carries through on some of these protectionist measures, against China or Japan, or other countries, he could get into a kind of trade war, everything will escalate and everybody will be alarmed. Plus, I think the international system requires a kind of hegemonic power to keep it going. The United States was that kind of power in the last 30-40 years, creating the WTO, the United Nation system and so on. If the US, basically, pulls back from that role, I think all of these international institutions will be vulnerable.

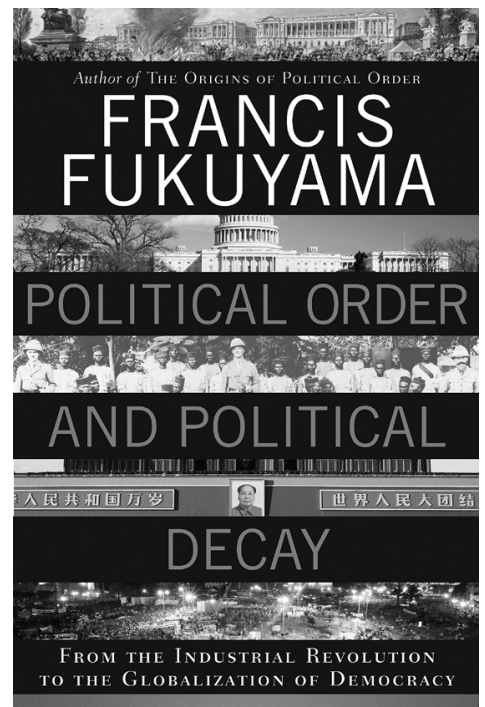

What do you think about the future American-Chinese relationships, since they are very important for the world market?

Again, he has not set a good initial direction because of this conversation with the President of Taiwan. He, I think, wants to build some leverage against China, but he may underestimate their power.

The Oxford Dictionary declared post-truth the word of the year 2016. We enter an accelerated postmodernism that allows the manipulation of identities, so that you do not know if the truth makes sense. How can you see the impact of post-truth in divided societies with multiple or even contradictory identities, like Moldova and Ukraine?

There are several different levels in that. The question of identities has been around for a long time. The more disturbing thing concerns facts. I think postfacts are a better designation than post truth, because we really don't know what the truth is, but at least we believe that we have plausible facts. I think what is really disturbing is that it starts with Putin. Putin is the one that put together all of these bad facts, for example the plane the Ukrainians presumably shot down, $\mathrm{MH}$ 17, the claim that they are crucifying children and doing all of these terrible things that are just completely false. Trump just picked this up, like a source of routine lies, e.g., the claim that the crime rate has been the highest [in forty-five years], the claim about all these illegal immigrants voting in the election. It is social media and the Internet that makes it possible, because it has 


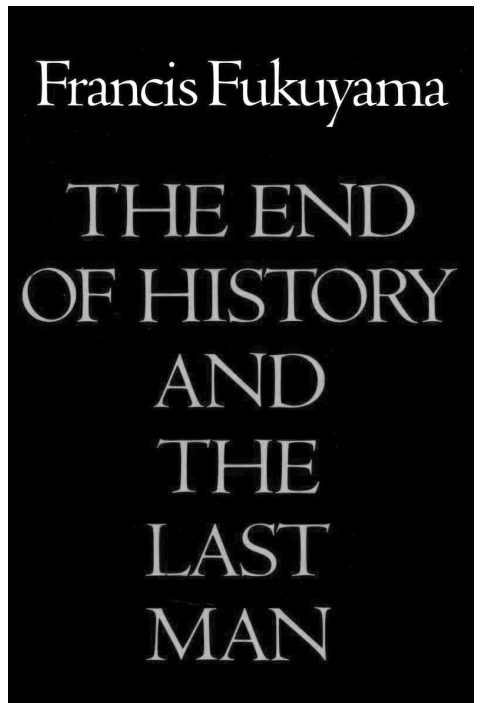

eliminated all the keepers to the information that could verify and assure the quality of the information that has been passed on. Now, anybody can say anything on the Internet. You get all of those conspiracy theories, a lot of people want to believe them, and they see that other people believe that, and they think that is good enough to verify that this is a true theory. I think that we live in a very dangerous world; that is my prospect.

Could we see some optimistic projects for this divided society? Is it possible to create a common identity for these divided societies?

I think that we have to keep the belief in a kind of liberal world; we have to push back and fight for that. You have to denounce people that put out these conspiracy theories, you have to put out good information, you have to defend the institutions that produce the information that we, actually, rely on.

Probably we need a clear vision for our future development. Yes.

What do you think about the perspectives of the European Union in the context of Brexit and the recent political changes in France, Hungary, Bulgaria, Romania, etc.?

It looks like the balance is shifting towards the more populist, anti- EU parts of the population. However, it's probably good to step back, like in the case of the Austrian election - a lot of people expected one of these populists to win, and he didn't. There is actually some evidence that the Europeans were looking at the Americans and said 'no, we don't want to be like America. We don't want to elect an idiot like Donald Trump.' Maybe people have more sense in Europe and hopefully they will keep nationalism away from political power.

But in some countries, they had some success, let's say, in Hungary. That's right.

So, the Hungarian leader is very popular inside the country. Putin in Russia is another case. But let us speak about the EU and Hungary, where the leader of the country is very popular.

Yes. I think that the rest of the EU didn't do a good job in opposing some of the things that he tried to do. I think that the German Christian Democrats bear a lot of the blame for that, because they were really the ones who should 
have pushed back when he closed down alternative media, NGOs and so forth. But I think they, too, were interested in maintaining the center-right coalition in the European parliament.

We will see next year what's happening in Germany itself, because the elections are coming. Many other things are going to happen next year. So, the last question is: how would you characterize the post-Soviet states after 25 years of independence and this long transition? Why is the transition process so long, why were there so many mistakes and failures?

First of all, I don't think there have been so many mistakes and failures. Communism left a terrible legacy that really undermined trust in institutions and required that you create a market economy and a democratic political system. It caused a lack of trust, it undermined the possibility of a good government and encouraged a lot of corruption. In a certain way, it's not surprising that 25 years after communism there still are countries that are struggling with that legacy. What is more disturbing is the cyclical nature of this process, where there's a great deal of enthusiasm for democracy in the 1990 s and then a kind of decrease in the 2000s. Now there seems to be a new wave of distrust of the democratic institutions and a kind of nostalgia for an authoritarian government, which, I think, is, probably, a kind of natural cycle. The older people get and the further they are from Communism, the more they forget how bad it was. In a way, they tell themselves that there was a better time under Communism. I think this is also dangerous.

We have enough reasons to be optimistic and to say that it is not the end of the history, that it is just a new beginning, don't we?

I think right now we are on a knife's edge, when we could go backward or forward. That is why I think that people who want to live in a more liberal world need to push for it strongly.

But from a Moldovan point of view, we can say that we are making a step forward and a couple of steps backward, at the same time. So, we cannot see any real optimistic future. And then the question is: how to fight these impediments in building an open society and a real democracy?

Right.

Thank you very much. Happy Holidays! 


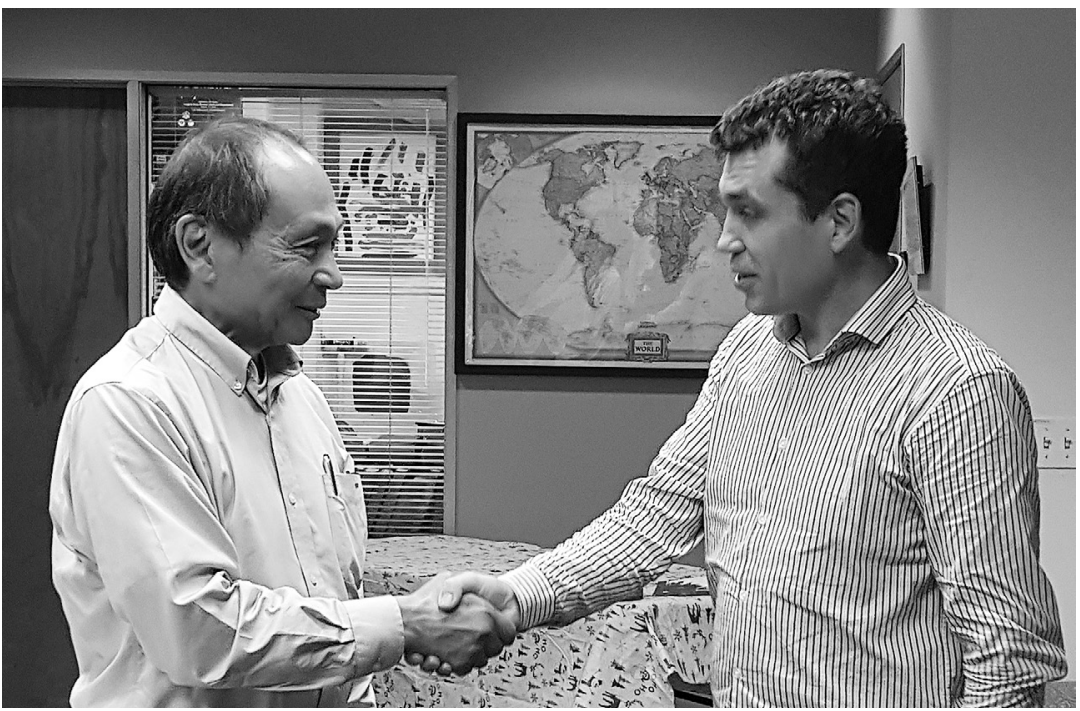

Francis FUKUYAMA is the Olivier Nomellini Senior Fellow at the Freeman Spogli Institute for International Studies (FSI) and the Mosbacher Director of FSI's Center on Democracy, Development, and the Rule of Law (CDDRL). $\mathrm{He}$ is also a professor by courtesy in the Department of Political Science. He was previously at the Paul H. Nitze School of Advanced International Studies (SAIS) of Johns Hopkins University, where he was the Bernard L. Schwartz Professor of International Political Economy and director of SAIS' International Development program.

Dr. Fukuyama has written widely on issues relating to questions concerning democratization and international political economy. His book, The End of History and the Last Man, was published by Free Press in 1992 and has appeared in over twenty foreign editions. His most recent book is Political Order and Political Decay: From the Industrial Revolution to the Globalization of Democracy.

Francis Fukuyama received his B.A. from Cornell University in classics, and his Ph.D. from Harvard in Political Science. He was a member of the Political Science Department of the RAND Corporation, and twice member of the Policy Planning Staff of the US Department of State. From 1996-2000 he was Omer L. and Nancy Hirst Professor of Public Policy at the School of Public Policy at George Mason University. He served as a member of the President's Council on Bioethics from 2001-2004.

Dr. Fukuyama is chairman of the editorial board of The American Interest, which he helped to found in 2005. He holds honorary doctorates from Connecticut College, Doane College, Doshisha University (Japan), and Kansai University (Japan). He is a member of the Board of Governors of the Pardee Rand Graduate School, and of the Volcker Alliance. He is a member of the American Political Science Association and the Council on Foreign Relations. He is married to Laura Holmgren and has three children. 